\title{
Toll-like receptor 4 Asp299Gly and Thr399lle polymorphisms: New data and a meta-analysis
}

\author{
Nezha Senhaji ${ }^{1 *}$, Brehima Diakit ${ }^{1}$, Nadia Serbati ${ }^{1}$, Younes Zaid ${ }^{3}$, Wafaa Badre ${ }^{2}$ and Sellama Nadifi ${ }^{1}$
}

\begin{abstract}
Background: The pathogenesis of inflammatory bowel disease (IBD) involves interactions between the host genetic susceptibility, intestinal microflora and mucosal immune responses through the pattern recognition receptor. Polymorphisms in toll-like receptor 4 (TLR4) induce an aberrant immune response to indigenous intestinal flora, which might favor IBD development. In this study, we aimed to determine whether TLR4 gene was associated with Crohn s disease (CD) and ulcerative colitis (UC) among Moroccan patients, and evaluated its correlation with clinical manifestation of the disease.
\end{abstract}

Methods: The study population comprised 117 patients with IBD and 112 healthy unrelated blood donors. TLR4 polymorphisms: Asp299Gly and Thr399lle were genotyped by polymerase chain reaction-restriction fragment length polymorphism. PCR products were cleaved with Nco I for the Asp299Gly polymorphism and Hinf I for the Thr399lle polymorphism. Meta-analysis was performed to test the association of 299Gly and 399lleu carriage with CD, UC and the overall IBD risk.

Results: Our study revealed that the frequency of Asp299Gly and Thr399lle did not differ significantly between patients and controls in the Moroccan population. However, meta-analysis demonstrated significantly higher frequencies of both Asp299Gly and Thr3991le SNPs in IBD and CD and for 399lleu carriage in UC patients.

Conclusion: The meta-analysis provides evidence that TLR4 polymorphisms confer a significant increased risk for the overall IBD development.

Keywords: Toll-like receptor 4, Inflammatory bowel disease, Moroccan patients

\section{Background}

Inflammatory bowel disease (IBD) is an idiopathic and chronic multifactorial disease of the gastrointestinal tract. Although the precise etiology of IBD is unclear, several factors that play a crucial role in disease pathogenesis such as commensal bacterial flora and genes related to the host immune response have been identified [1,2].

Toll-like receptors are pattern recognition receptors through which host recognizes microbial conserved molecular motifs that are broadly shared by pathogens, therefore they are very important for the regulation of mucosal innate immune responses to intestinal microbes. Perturbations in individual TLR biological signaling can prime to a

\footnotetext{
*Correspondence: nezha.senhaji@gmail.com

'Laboratory of Genetic and Molecular Pathology (LGPM), Medical School, Hassan II University, Casablanca, Morocco

Full list of author information is available at the end of the article
}

number of different outcomes and elucidate a system of regulation within the intestine in which each TLR plays a largely non-redundant role in mucosal immunity.

TLR4 gene, the first mammalian TLR identified is located on the long arm of human chromosome 9q32-33 [3]. It encodes the transmembrane receptor that initiates the innate immune response to common gram-negative bacteria $[4,5]$.

TLR4 is the major transducer of lipopolysaccharide (LPS) and binds specifically lipid A moiety. Signal transduction through TLR4 in combination with CD14, and MD-2 leads to activation of the nuclear factor- $\mathrm{kB}$ (NF- $\mathrm{kB}$ ) system through the MyD88-dependent and MyD88-independent pathways and subsequent expression of inflammatory genes encoding cytokines and cell conjugation molecules as part of host defense mechanisms [6-9].

Under healthy conditions TLR4 is only minimally expressed in lamina propria mononuclear cells (LPMNCs) 
and intestinal epithelial cells which are partly tolerant to LPS, thus preventing an exaggerated immune response mediated by the large number of bacteria in the intestinal lumen and maintaining a basal state of activation [10,11].

However, TLR4 expression is upregulated in human IBD colitis, maximizing responsiveness to the environment and reflecting an aberrant state of activation [12-15]. Higher levels of TLR4 mRNA and protein were found in the inflamed colonic mucosa in pediatric IBD patients [16]. Two common cosegregating polymorphisms affecting the extracellular domain of the TLR4 (Asp299Gly and Thr399Ile) have been described in humans. Individuals heterozygous for these mutations have a blunted response to inhaled LPS [17]. These polymorphisms are thought to be associated with increased susceptibility to IBD. However, population studies reveal discordant results in geographical distribution.
Thereby, we sought to investigate whether Asp299Gly and Thr399Ile single nucleotide polymorphisms of the gene encoding the TLR4 determine susceptibility to IBD in Moroccan patients and assessed their influence on phenotype expression.

\section{Methods}

\section{Study population}

Enrolled in this study were 117 IBD Moroccan patients (83 CD; 34 UC) and 112 healthy unrelated blood donors. The diagnosis of $\mathrm{CD}$ or $\mathrm{UC}$ was established according to conventional clinical, endoscopic, radiological and histological criteria as previously reported $[18,19]$. CD was classified according to the Montreal classification [20].

The case report form included questions on disease phenotype and location, age at diagnosis, toxic behavior and other clinical features. The ethics committee of the

Table 1 Pooled analysis of studies exploring the role of TLR4 Asp299Gly in CD

\begin{tabular}{|c|c|c|c|c|c|}
\hline Study & Cases (Events/Total) & Controls (Events/Total) & Odds ratio & $95 \% \mathrm{Cl}$ & $P$ value \\
\hline Arnott et al. 2004 [31] & $50 / 468$ & $33 / 378$ & 1,25 & 0,79 to 1,98 & \\
\hline Franchimont et al. 2004 [32] (1) & $73 / 668$ & $14 / 278$ & 2,31 & 1,28 to 4,17 & \\
\hline Franchimont et al. 2004 [32] (2) & $26 / 226$ & $14 / 278$ & 2,45 & 1,25 to 4,81 & \\
\hline Torok et al. 2004 [33] & $14 / 204$ & $12 / 290$ & 1,70 & 0,77 to 3,77 & \\
\hline Braat et al. 2005 [34] & $68 / 822$ & $13 / 274$ & 1,81 & 0,98 to 3,33 & \\
\hline Brand et al. 2005 [22] & $29 / 408$ & $15 / 398$ & 1,95 & 1,03 to 3,70 & \\
\hline Lakatos et al. 2005 [35] & $104 / 1054$ & $48 / 400$ & 0,80 & 0,56 to 1,15 & \\
\hline Gazouli et al. 2005 [36] & $19 / 240$ & $6 / 200$ & 2,78 & 1,09 to 7,10 & \\
\hline Oostenbrug et al. 2005 [37] & $53 / 786$ & $27 / 592$ & 1,51 & 0,94 to 2,43 & \\
\hline Ouburg et al. 2005 [38] & $23 / 224$ & $18 / 340$ & 2,04 & 1,08 to 3,88 & \\
\hline Fries et al. 2005 [39] (1) & $2 / 46$ & $2 / 118$ & 2,63 & 0,36 to 19,29 & \\
\hline Fries et al. 2005 [39] (2) & $10 / 120$ & $2 / 118$ & 5,27 & 1,13 to 24,60 & \\
\hline Zouiten-Mekki et al. 2009 [40] & $12 / 180$ & $9 / 160$ & 1,19 & 0,49 to 2,92 & \\
\hline Hong et al. 2007 [41] & $26 / 364$ & $32 / 376$ & 0,82 & 0,48 to 1,42 & \\
\hline Baumgart et al. 2007 [21] (1) & $6 / 288$ & $16 / 404$ & 0,51 & 0,20 to 1,33 & \\
\hline Baumgart et al. 2007 [21] (2) & $28 / 482$ & $49 / 806$ & 0,95 & 0,59 to 1,54 & \\
\hline Browning et al. 2007 [42] & $50 / 778$ & $44 / 832$ & 1,23 & 0,81 to 1,86 & \\
\hline De Ridder et al. 2007 [23] (1) & $11 / 144$ & $20 / 488$ & 1,93 & 0,91 to 4,14 & \\
\hline De Ridder et al. 2007 [23] (2) & $63 / 756$ & $20 / 488$ & 2,12 & 1,27 to 3,56 & \\
\hline Riis et al. 2007 [43] & $32 / 422$ & $152 / 1236$ & 0,58 & 0,39 to 0,87 & \\
\hline Hume et al. 2008 [44] & $87 / 1238$ & $36 / 720$ & 1,43 & 0,96 to 2,14 & \\
\hline Rigoli et al. 2008 [45] & $10 / 266$ & $8 / 206$ & 0,96 & 0,38 to 2,49 & \\
\hline Manolakis et al. 2013 [46] & $20 / 326$ & $33 / 548$ & 1,02 & 0,58 to 1,81 & \\
\hline Current study 2014 & $9 / 166$ & $10 / 224$ & 1,22 & 0,49 to 3,09 & \\
\hline Total (fixed effects) & $825 / 10676$ & $633 / 10152$ & 1,26 & 1,13 to 1,42 & 0.0001 \\
\hline Total (random effects) & $825 / 10676$ & 633/10152 & 1,35 & 1,12 to 1,64 & \\
\hline
\end{tabular}


Faculty of Medicine and Pharmacy of Casablanca approved the study and a written informed consent was obtained from all human subjects.

\section{Molecular analysis of TLR4 polymorphisms}

Genomic DNA was extracted from peripheral blood leukocytes using the salting out procedure. Two single nucleotide variations, corresponding to two amino acid polymorphisms for TLR4, were analyzed: the Asp299Gly (896A/G), rs4986790 and the Thr399Ile (1196C/T), rs4986791.

Typing of the polymorphisms was performed using polymerase chain reaction (PCR) restriction fragment length polymorphism analysis (RFLP).

Upstream and downstream primers used for the PCR amplification were:

F: (5' - AGCATACTTAGACTACTACCTCCATG-3'),

R: (5'- GAGAGATTTGAGTTTCAATGTGGG-3') for TLR4Asp299Gly

And F: (5'-GGTTGCTGTTCTCAAAGTGATTTTGGG AGAA- $\left.3^{\prime}\right)$,

R:(5'-GGAAATCCAGATGTTCTAGTTGTTCTAAGCC-

3') for TLR4Thr399Ile.

Reactions were performed in a $25 \mu \mathrm{l}$ volume containing $200 \mu \mathrm{M}$ of each dNTP $(0.5 \mu \mathrm{l}$ of dNTP mix, $10 \mathrm{mM}$ each), $0.2 \mu \mathrm{M}$ of each of the forward and reverse primers $(0.5 \mu \mathrm{l}$ of each $10 \mu \mathrm{M}$ primers), $2 \mathrm{mM} \mathrm{MgCl} 2(1 \mu \mathrm{l}$ of $\mathrm{MgCl} 2$,
$50 \mathrm{mM})$ and $1 \mathrm{U}$ of Taq DNA polymerase $(1 \mu \mathrm{l}$ of $1 \mathrm{U} / \mu \mathrm{l}$ enzyme), 1 PCR buffer ( $2.5 \mu \mathrm{l}$ of 10 PCR buffer).

PCR conditions comprised $5 \mathrm{~min}$ at $95 \mathrm{C}$ then $35 \mathrm{cy}-$ cles of denaturing were performed at $95 \mathrm{C}$ for $30 \mathrm{~s}$, annealing at 55C (Asp299Gly) and at 53C (Thr399Ile) for $1 \mathrm{~min}, 72 \mathrm{C}$ for $30 \mathrm{~s}$. A final extension phase of $72 \mathrm{C}$ for 10 minutes was used.

PCR products were cleaved overnight at $37 \mathrm{C}$ with Nco I for Asp299Gly polymorphism and Hinfl for Thr399Ile polymorphism (Biolabs). The digests were run on a 3\% agarose gel and visualized under UV light using ethidium bromide.

The mutant alleles (GG)/(TT) contained an Nco I/ Hinf I restriction site for the Asp299Gly/Thr399Ile polymorphisms respectively, allowing RFLP analysis of the digested products. Digestion at the Nco I site yields fragments of 168 and $20 \mathrm{bp}$, the one at Hinf I site yields fragments of 98 and $26 \mathrm{bp}$. The wild-type allele for both polymorphisms remained uncut.

\section{Statistical analysis}

The data were analyzed with MedCalc 11.6. Chi-square test was used to compare the allele and genotype frequencies between disease and control groups. The Fisher s exact test was used when appropriate. The observed genotype frequencies were compared with the predicted frequencies by the Hardy Weinberg equilibrium.

The average age was determined by the rank sum test. Associations between genotypes and risk of IBD were

Table 2 Pooled analysis of studies exploring the role of TLR4 Asp299Gly in UC

\begin{tabular}{|c|c|c|c|c|c|}
\hline Study & Cases (Events/Total) & Controls (Events/Total) & Odds ratio & $95 \% \mathrm{Cl}$ & $P$ value \\
\hline Arnott et al. 2004 [31] & $35 / 492$ & $33 / 378$ & 0,801 & 0,49 to 1,31 & \\
\hline Franchimont et al. (1) 2004 [32] & $32 / 326$ & $14 / 278$ & 2,052 & 1,07 to 3,93 & \\
\hline Torok et al. 2004 [33] & $18 / 196$ & $12 / 290$ & 2,343 & 1,10 to 4,98 & \\
\hline Braat et al. 2005 [34] & $24 / 452$ & $13 / 274$ & 1,126 & 0,56 to 2,25 & \\
\hline Gazouli et al. 2005 [36] & $6 / 170$ & $6 / 200$ & 1,183 & 0,37 to 3,73 & \\
\hline Oostenbrug et al. 2005 [37] & $21 / 358$ & $27 / 592$ & 1,304 & 0,72 to 2,34 & \\
\hline Baumgart et al. 2007 [21] (1) & $8 / 236$ & $16 / 404$ & 0,851 & 0,36 to 2,02 & \\
\hline Baumgart et al. 2007 [21] (2) & $24 / 290$ & $49 / 806$ & 1,394 & 0,84 to 2,31 & \\
\hline Browning et al. 2007 [42] & $51 / 810$ & $44 / 832$ & 1,203 & 0,79 to 1,82 & \\
\hline Riis et al. 2007 [43] & $53 / 808$ & $152 / 1236$ & 0,501 & 0,36 to 0,69 & \\
\hline De Ridder et al. 2007 [23] (1) & $33 / 452$ & $20 / 488$ & 1,843 & 1,04 to 3,26 & \\
\hline De Ridder et al. 2007 [23] (2) & $4 / 62$ & $20 / 488$ & 1,614 & 0,53 to 4,88 & \\
\hline Rigoli et al. 2008 [45] & $3 / 90$ & $8 / 206$ & 0,853 & 0,22 to 3,29 & \\
\hline Manolakis et al. 2013 [46] & $41 / 374$ & $33 / 548$ & 1,921 & 1,19 to 3,10 & \\
\hline Current study 2014 & $6 / 68$ & $10 / 224$ & 2,071 & 0,72 to 5,92 & \\
\hline Total (fixed effects) & $359 / 5184$ & $457 / 7244$ & 1,092 & 0,94 to 1,26 & 0.20 \\
\hline Total (random effects) & $359 / 5184$ & $457 / 7244$ & 1,268 & 0,95 to 1,69 & \\
\hline
\end{tabular}


estimated by calculating odds ratio (OR) with confidence interval of $95 \%$ (CI). $P$ values less than 0.05 were considered significant in disease risk association tests. The $x^{2}$ test or Fisher test was used to correlate the TLR4 polymorphisms and clinical parameters. The Bonferroni correction method was applied for correction for multiple testing in sub-phenotype analysis; The phenotype genotype correlation was considered statistically significant if the $p$ value was less than 0.005 for $\mathrm{CD}$ and 0.007 for UC. According to Power Calculator for Genetic Studies 2006 software (http://www.sph.umich.edu/csg/abecasis/CaTS/), this study had $15 \%$ of power to detect an OR of 1.5 .

\section{TLR4 meta-analysis}

\section{Inclusion and exclusion criteria}

Genetic association studies were included in our metaanalysis if they met the following criteria:

(a) Studies that evaluated the association between the TLR4 Asp299Gly, Thr399Ile polymorphisms and IBD, (b) A case control study design, (c) The study reported sufficient data to calculate allele frequencies, odds ratios and confidence intervals of cases and controls for carriage of the TLR4 299Gly and 399Ile alleles.

While major exclusion criteria were: (a) case-only study and review articles (b) absence of the mutant allele in both cases and controls, (c) studies without the raw data of the TLR4 Asp299Gly and Thr399Ile genotypes.

\section{Pooled studies for case control meta-analysis}

Twenty-four case control studies were identified through the literature search.

Asp299Gly polymorphism: According to the inclusion criteria, twenty studies were retrieved in CD metaanalysis (Table 1), four of them contained more than one cohort [21-24]. UC meta-analysis reported data from 13 of the included studies (Table 2); two of them

Table 3 Pooled analysis of studies exploring the role of TLR4 Thr399lle in CD

\begin{tabular}{|c|c|c|c|c|c|c|}
\hline Study & Sample size & Cases (Events/Total) & Controls (Events/Total) & Odds ratio & $95 \% \mathrm{Cl}$ & $P$ value \\
\hline \multirow[t]{2}{*}{ Torok et al. 2004 [33] } & CD: 102 & $16 / 204$ & $12 / 290$ & 1.972 & 0.91 to 4.26 & \\
\hline & HC: 145 & & & & & \\
\hline \multirow[t]{2}{*}{ Braat et al. 2005 [34] } & CD: 204 & $30 / 408$ & $19 / 398$ & 1.583 & 0.87 to 2.86 & \\
\hline & HC: 199 & & & & & \\
\hline \multirow[t]{2}{*}{ Gazouli et al. 2005 [36] } & CD: 120 & $1 / 240$ & $2 / 200$ & 0.414 & 0.037 to 4.60 & \\
\hline & HC: 100 & & & & & \\
\hline \multirow[t]{2}{*}{ Oostenbrug et al. 2005 [37] } & CD: 393 & $69 / 1008$ & $29 / 598$ & 1.442 & 0.92 to 2.25 & \\
\hline & HC: 296 & & & & & \\
\hline \multirow[t]{2}{*}{ Zouiten-Mekki et al. 2009 [40] } & CD: 90 & $13 / 180$ & $8 / 160$ & 1.479 & 0.59 to 3.66 & \\
\hline & HC: 80 & & & & & \\
\hline \multirow[t]{2}{*}{ Hong et al. 2007 [41] } & CD: 182 & $30 / 364$ & $32 / 376$ & 0.966 & 0.57 to 1.62 & \\
\hline & HC: 188 & & & & & \\
\hline \multirow[t]{2}{*}{ Browning et al. 2007 [42] } & CD: 389 & $47 / 778$ & $46 / 832$ & 1.099 & 0.72 to 1.67 & \\
\hline & HC: 416 & & & & & \\
\hline \multirow[t]{2}{*}{ De Ridder et al. 2007 [23] } & CD: 450 & $72 / 900$ & $22 / 488$ & 1.842 & 1.12 to 3.00 & \\
\hline & HC: 244 & & & & & \\
\hline \multirow[t]{2}{*}{ Rigoli et al. 2008 [45] } & CD: 133 & $8 / 266$ & $6 / 206$ & 1.034 & 0.35 to 3.02 & \\
\hline & HC:103 & & & & & \\
\hline \multirow[t]{2}{*}{ Azzam et al. 2012 [47] } & CD: 46 & 26/92 & $22 / 100$ & 1.397 & 0.72 to 2.69 & \\
\hline & HC: 50 & & & & & \\
\hline \multirow[t]{2}{*}{ Manolakis et al. 2013 [46] } & CD: 163 & $20 / 326$ & $33 / 548$ & 1.020 & 0.57 to 1.80 & \\
\hline & HC: 274 & & & & & \\
\hline \multirow[t]{2}{*}{ Our study 2014} & CD: 83 & $7 / 166$ & $3 / 224$ & 3.243 & 0.82 to 12.73 & \\
\hline & HC: 112 & & & & & \\
\hline Total (fixed effects) & & $339 / 4932$ & $234 / 4420$ & 1.345 & 1.12 to 1.60 & 0.002 \\
\hline Total (random effects) & & $339 / 4932$ & $234 / 4420$ & 1.336 & 1.11 to 1.59 & \\
\hline
\end{tabular}


Table 4 Pooled analysis of studies exploring the role of TLR4 Thr399lle in UC

\begin{tabular}{|c|c|c|c|c|c|c|}
\hline Study & Sample size & Cases (Events/Total) & Controls (Events/Total) & Odds & $95 \% \mathrm{Cl}$ & $P$ value \\
\hline \multirow[t]{2}{*}{ Torok et al. 2004 [33] } & UC: 98 & $22 / 196$ & $12 / 290$ & 2.929 & 1.41 to 6.06 & \\
\hline & HC: 145 & & & & & \\
\hline \multirow[t]{2}{*}{ Gazouli et al. 2005 [36] } & UC: 85 & $3 / 170$ & $2 / 200$ & 1.778 & 0.29 to 10.77 & \\
\hline & HC: 100 & & & & & \\
\hline \multirow[t]{2}{*}{ Oostenbrug et al. 2005 [37] } & UC: 179 & $24 / 434$ & $19 / 598$ & 1.784 & 0.96 to 3.30 & \\
\hline & HC: 296 & & & & & \\
\hline \multirow[t]{2}{*}{ Zouiten-Mekki et al. 2009 [40] } & UC: 30 & $2 / 60$ & $2 / 160$ & 2.724 & 0.37 to 19.78 & \\
\hline & $\mathrm{HC}: 80$ & & & & & \\
\hline \multirow[t]{2}{*}{ Browning et al. 2007 [42] } & UC: 405 & $59 / 810$ & $46 / 832$ & 1.342 & 0.90 to 1.99 & \\
\hline & HC: 416 & & & & & \\
\hline \multirow[t]{2}{*}{ De Ridder et al. 2007 [23] } & UC: 257 & $34 / 514$ & $22 / 488$ & 1.500 & 0.86 to 2.60 & \\
\hline & HC: 244 & & & & & \\
\hline \multirow[t]{2}{*}{ Rigoli et al. 2008 [45] } & UC: 45 & $3 / 90$ & $6 / 206$ & 1.149 & 0.28 to 4.70 & \\
\hline & HC:103 & & & & & \\
\hline \multirow[t]{2}{*}{ Manolakis et al. 2013 [46] } & UC: 187 & $41 / 374$ & $33 / 548$ & 1.921 & 1.19 to 3.10 & \\
\hline & HC: 274 & & & & & \\
\hline \multirow[t]{2}{*}{ Our study 2014} & UC: 34 & $3 / 68$ & $3 / 224$ & 3.400 & 0.67 to 17.25 & \\
\hline & HC: 112 & & & & & \\
\hline Total (fixed effects) & & $191 / 2716$ & $145 / 3546$ & 1.695 & 1.35 to 2.11 & 0.0001 \\
\hline Total (random effects) & & $191 / 2716$ & $145 / 3546$ & 1.699 & 1.35 to 2.12 & \\
\hline
\end{tabular}

contained more than one cohort [21,22]. Six studies met one of the exclusion criteria [25-30].

Thr399Ile Polymorphism: twelve studies comprising 2466 cases and 2210 controls were included in CD meta-analysis (Table 3), and nine of them in UC metaanalysis with 1358 cases and 1773 controls (Table 4). A meta-analysis combining CD and UC patients for the two tested SNPs: Asp299Gly and Thr399Ile included 13 and 9 studies respectively (Tables 5 and 6).

The risk of IBD associated with the TLR4 polymorphism was estimated for each study by odds ratio (OR) and 95\% confidence interval (95\% CI). The meta-ORs were estimated using a fixed-effects model with the wild-type allele as reference group. Genetic heterogeneity was tested by Cochran s (Q) test, $\mathrm{I}^{2}$ statistics was used to quantify the between-study heterogeneity effect. When a significant $\mathrm{Q}$ test $\left(\mathrm{Q}>0.10 ; \mathrm{I}^{2}>50 \%\right)$ indicated heterogeneity across studies, data were recombined using a random-effects model to estimate common ORs. The meta-analyses were conducted by Review Manager 5.0 and MedCalc bvba 12.3.0 softwares.

\section{Results}

Hundred and seventeen patients with IBD (83 CD; 34 UC) and 112 control subjects from the general population were genotyped for the presence of TLR4Asp299Gly and Thr399Ile polymorphisms.

The average age of CD, UC patients and controls was $27.62 .3,405.0$ and 31.32 .1 years respectively. The distributions of genotype and allele frequencies of both TLR4Asp299Gly and Thr399Ile polymorphisms in CD patients $(\mathrm{X} 2=0.03, \mathrm{P}=0.86 ; \mathrm{X} 2=0.02, \mathrm{P}=0.90)$ and healthy controls $(\mathrm{X} 2=2.86, \mathrm{P}=0.24 ; \mathrm{X} 2=0.01, \mathrm{P}=0.94)$ were in Hardy-Weinberg equilibrium. In patients with UC, genotype and allele frequencies distributions for Asp299Gly polymorphism (X2 $=0.03, \mathrm{P}=0.86$ ) were in Hardy-Weinberg equilibrium but not for Th399ILeu polymorphism $(\mathrm{X} 2=19.05, \mathrm{P}<0.001)$.

In order to study associations of TLR4 variants in IBD overall and in CD and UC in particular, the distribution of TLR4 polymorphic alleles was assessed. Genotype and allele frequencies are given in Table 7 and genotypic and allelic odds ratios and test P-values are presented in Table 8. None CD nor UC colitis patients were homozygous for $\mathrm{G}$ allele. Mutant allele frequency was $5.4 \%$ in $\mathrm{CD}, 8.8 \%$ in $\mathrm{UC}$ and $4.5 \%$ in $\mathrm{HC}$. No significant difference was noticed in allele distributions of the Asp299Gly polymorphism between the control and patient groups. Likewise, no significant association of IBD with the Thr399Ile polymorphism was found in either cohort (allele frequencies: $\mathrm{HC}$ 1.3\%, CD 
Table 5 Pooled analysis of studies exploring the role of TLR4 Asp299Gly in IBD

\begin{tabular}{|c|c|c|c|c|c|c|}
\hline Study & Sample size & Cases (Events/Total) & Controls (Events/Total) & Odds ratio & $95 \% \mathrm{Cl}$ & $P$ value \\
\hline \multirow[t]{2}{*}{ Arnott et al. 2004 [31] } & IBD: 480 & $85 / 960$ & $33 / 378$ & 1,016 & 0,667 to 1,54 & \\
\hline & HC: 189 & & & & & \\
\hline \multirow[t]{2}{*}{ Franchimont et al. 2004 [32] } & IBD: 610 & $131 / 1220$ & $14 / 278$ & 2,268 & 1,286 to 4,00 & \\
\hline & HC: 139 & & & & & \\
\hline \multirow[t]{2}{*}{ Torok et al. 2004 [33] } & IBD: 200 & $32 / 400$ & $12 / 290$ & 2,014 & 1,019 to 3,98 & \\
\hline & HC: 145 & & & & & \\
\hline \multirow[t]{2}{*}{ Braat et al. 2005 [34] } & IBD: 637 & $92 / 1274$ & $13 / 274$ & 1,563 & 0,861 to 2,83 & \\
\hline & HC: 137 & & & & & \\
\hline \multirow[t]{2}{*}{ Gazouli et al. 2005 [36] } & IBD: 205 & $25 / 410$ & $6 / 200$ & 2,100 & 0,847 to 5,20 & \\
\hline & HC: 100 & & & & & \\
\hline \multirow[t]{2}{*}{ Oostenbrug et al. 2005 [37] } & IBD: 572 & $74 / 1144$ & $27 / 592$ & 1,447 & 0,921 to 2,27 & \\
\hline & HC: 296 & & & & & \\
\hline \multirow[t]{2}{*}{ Baumgart et al. 2007 [21] (1) } & IBD: 262 & $14 / 524$ & $16 / 404$ & 0,666 & 0,321 to 1,38 & \\
\hline & HC: 202 & & & & & \\
\hline \multirow[t]{2}{*}{ Baumgart et al. 2007 [21] (2) } & IBD: 386 & $52 / 772$ & $49 / 806$ & 1,116 & 0,745 to 1,67 & \\
\hline & HC: 403 & & & & & \\
\hline \multirow[t]{2}{*}{ Browning et al. 2007 [42] } & IBD: 796 & $101 / 1592$ & $44 / 832$ & 1,213 & 0,843 to 1,74 & \\
\hline & HC: 416 & & & & & \\
\hline \multirow[t]{2}{*}{ Riis et al. 2007 [43] } & IBD: 615 & $85 / 1230$ & $152 / 1236$ & 0,529 & 0,401 to 0,69 & \\
\hline & HC: 618 & & & & & \\
\hline De Ridder et al. 2007 [23] & IBD: 103 & $15 / 206$ & $20 / 488$ & 1,838 & 0,921 to 3,66 & \\
\hline \multirow[t]{2}{*}{ De Ridder et al. 2007 [23] } & IBD: 604 & $96 / 1208$ & $20 / 488$ & 2,020 & 1,233 to 3,31 & \\
\hline & HC: 244 & & & & & \\
\hline \multirow[t]{2}{*}{ Rigoli et al. 2008 [45] } & IBD: 178 & $13 / 356$ & $8 / 206$ & 0,938 & 0,382 to 2,30 & \\
\hline & HC: 103 & & & & & \\
\hline \multirow[t]{2}{*}{ Manolakis et al. 2013 [46] } & IBD: 350 & $61 / 700$ & $33 / 548$ & 1,490 & 0,960 to 2,31 & \\
\hline & HC: 274 & & & & & \\
\hline \multirow[t]{2}{*}{ Our study 2014} & IBD:117 & $15 / 234$ & $10 / 224$ & 1,466 & 0,644 to 3,33 & \\
\hline & $H C: 112$ & & & & & \\
\hline \multicolumn{2}{|l|}{ Total (fixed effects) } & $891 / 12230$ & $457 / 7244$ & 1,154 & 1,021 to 1,30 & 0.015 \\
\hline \multicolumn{2}{|l|}{ Total (random effects) } & $891 / 12230$ & $457 / 7244$ & 1,306 & 1,006 to 1,69 & \\
\hline
\end{tabular}

4.2\%, UC 4.4\%). TT genotype was not observed in both $\mathrm{CD}$ patients and $\mathrm{HC}$ and only one individual carried the 399Ile variant at both alleles in UC. Co-segregation of TLR4 polymorphic alleles was observed in only $33 \%$ of controls (3 out of 9 ), 33\% in UC (2 out of 6 ) and $60 \%$ in CD (6 out of 10$)$.

Meta-analysis of our dataset with the published studies showed a significant association between TLR4 Asp299Gly variant allele and CD risk in a total of 5338 cases and 5076 controls (Pooled ORs $=1.35$, 95\% CI: 1.12-1.38; $\mathrm{P}=0.0001$ ) (Figure 1 ). In the other hand, no association with UC was found when evaluating disease risk in 2592 patients and 3622 controls (Table 2),
$\mathrm{OR}=1.27,95 \% \mathrm{CI}=0.95-1.69 ; \mathrm{P}=0.20$ (Figure 2 ). Heterogeneity in odds ratios between studies was evidenced for $C D\left(Q=54.5,23 \mathrm{df}, P=0.0002, \mathrm{I}^{2}=57.6 \%\right)$ and $\mathrm{UC}\left(\mathrm{Q}=43.4 \%, 14 \mathrm{df}, P=0.0001, \mathrm{I}^{2}=67.8\right)$.

Combining Asp299Gly results for CD and UC (6115 cases and 3622 controls), an overall significant increased risk for $\mathrm{IBD}$ was observed, $\mathrm{OR}=1.15,95 \% \mathrm{CI}=1.03$ 1.30; $\mathrm{P}=0.015$ (Figure 3). However, a significant heterogeneity in allelic frequencies distribution is reported (Cohrans Q = 52.9, $\mathrm{I}^{2}=73.6 \%$ ).

Based on the studies published so far combined to our results, we observed a significant association between the T allele of the TLR4Thr399Ile Polymorphism and both CD 
Table 6 Pooled analysis of studies exploring the role of TLR4 Thr399lle in IBD

\begin{tabular}{|c|c|c|c|c|c|c|}
\hline Study & Sample size & Cases (Events/Total) & Controls (Events/Total) & Odds & $95 \% \mathrm{Cl}$ & $P$ value \\
\hline \multirow[t]{2}{*}{ Torok et al. 2004 [33] } & IBD: 200 & $38 / 400$ & $12 / 290$ & 2.432 & 1.24 to 4.74 & \\
\hline & HC: 145 & & & & & \\
\hline \multirow[t]{2}{*}{ Gazouli et al. 2005 [36] } & IBD: 205 & $4 / 410$ & $2 / 200$ & 0.975 & 0.17 to 5.37 & \\
\hline & HC: 100 & & & & & \\
\hline \multirow[t]{2}{*}{ Oostenbrug et al. 2005 [37] } & IBD: 721 & $93 / 1442$ & $29 / 598$ & 1.353 & 0.88 to 2.07 & \\
\hline & HC: 299 & & & & & \\
\hline \multirow[t]{2}{*}{ Zouiten-Mekki et al. 2009 [40] } & IBD: 120 & $15 / 240$ & $8 / 160$ & 1.267 & 0.52 to 3.06 & \\
\hline & HC: 80 & & & & & \\
\hline \multirow[t]{2}{*}{ Browning et al. 2007 [42] } & IBD: 794 & $106 / 1588$ & $46 / 832$ & 1.222 & 0.85 to 1.74 & \\
\hline & HC: 416 & & & & & \\
\hline \multirow[t]{2}{*}{ De Ridder et al. 2007 [23] } & IBD: 707 & $106 / 1414$ & $22 / 488$ & 1.717 & 1.07 to 2.75 & \\
\hline & HC: 244 & & & & & \\
\hline \multirow[t]{2}{*}{ Rigoli et al. 2008 [45] } & IBD: 178 & $12 / 356$ & $6 / 206$ & 1.163 & 0.43 to 3.14 & \\
\hline & HC: 103 & & & & & \\
\hline \multirow[t]{2}{*}{ Manolakis et al. 2013 [46] } & IBD: 350 & $61 / 700$ & $33 / 548$ & 1.490 & 0.96 to 2.31 & \\
\hline & HC: 274 & & & & & \\
\hline \multirow[t]{2}{*}{ Our study 2014} & IBD: 117 & $10 / 234$ & $3 / 224$ & 3.289 & 0.89 to 12.11 & \\
\hline & HC: 112 & & & & & \\
\hline Total (fixed effects) & & $445 / 6784$ & $161 / 3546$ & 1.479 & 1.22 to 1.82 & 0.0001 \\
\hline Total (random effects) & & $445 / 6784$ & $161 / 3546$ & 1.465 & 1.21 to 1.80 & \\
\hline
\end{tabular}

and UC risk (Figures 4 and 5). As well, TLR4Thr399Ile variant increased the overall IBD susceptibility when combining $\mathrm{CD}$ and $\mathrm{UC}$ results $(\mathrm{OR}=1.46$, 95\%CI: 1.21 1.76 ; $\mathrm{P}<0.0001)$ for a total of 3392 cases and 1773 controls (Figure 6).

In the present meta-analysis, we did not observed heterogeneity between studies for TLR4Thr399Ile Polymorphism distribution in $\mathrm{CD}\left(\mathrm{Q}=9.05, \mathrm{DF}=11, \mathrm{I}^{2}=\right.$ -21.54\%; $\mathrm{P}=0.62)$, UC $\left(\mathrm{Q}=5.18\right.$, Df $=8, \mathrm{I}^{2}=-54.4 \%$; $\mathrm{P}=$ 0.73 ) and IBD (Cohran $\mathrm{SQ}=7.84, \mathrm{DF}=10, \mathrm{I}^{2}=-27.5 \%$; $\mathrm{P}=0.64)$.

Genotype-phenotype correlation was investigated; demographic and clinical characteristics of CD and UC patients according to TLR4 polymorphisms are shown in (Tables 9 and 10). A significant association was found between the need for surgery and possession of one or more Asp299gly variant alleles in UC patients $(\mathrm{P}=0.004)$. The presence of TLR4 variant alleles was not associated with smoking habits, age of diagnosis, disease location and behavior, family history and presence of extra-intestinal manifestations. Separate analyses in men and women did not reveal sex related associations. None of our UC patients had an appendectomy. The correlation study between Th399ILeu polymorphism and CD or UC didn $\mathrm{t}$ allow to associate TLR4 genotype with a particular phenotype.

\section{Discussion}

Given the evidence that an altered innate immune response and chronic inflammation are implicated in IBD

Table 7 Allele and genotype frequencies of the studied polymorphisms in the group of patients with Crohn s disease, ulcerative colitis and controls

\begin{tabular}{|c|c|c|c|c|c|c|c|c|c|c|}
\hline \multirow[t]{2}{*}{ Group } & \multicolumn{5}{|c|}{ TLR4 Asp299Gly } & \multicolumn{5}{|c|}{ TLR4 Thr399lle } \\
\hline & $\bar{A}$ & G & AA & AG & GG & $\bar{C}$ & $T$ & $\mathrm{CC}$ & CT & TT \\
\hline $\mathrm{CD}(\%) \mathrm{N}=83$ & $157(94.6)$ & $9(5.4)$ & $74(89.2)$ & $9(10.8)$ & - & $159(95.8)$ & $7(4.2)$ & $76(91.6)$ & $7(8.4)$ & - \\
\hline UC (\%) $N=34$ & $62(91.2)$ & $6(8.8)$ & $28(82.4)$ & $6(17.6)$ & - & 65 (95.6) & $3(4.4)$ & $32(94.1)$ & $1(2.9)$ & $1(2.9)$ \\
\hline Controls (\%) $\mathrm{N}=112$ & $214(95.5)$ & $10(4.5)$ & $103(92.0)$ & $8(7.1)$ & $1(0.9)$ & $221(98.7)$ & $3(1.3)$ & 109 (97.3) & $3(2.7)$ & - \\
\hline
\end{tabular}


Table 8 Odds ratios and P values for association of TLR4 variants with IBD status

\begin{tabular}{llllll}
\hline SNP & Trait & Genotype/Allele & OR & Cl & P Value \\
\hline Asp299Gly & CD & AG & 1.57 & $(0.58-4.25)$ & 0.38 \\
& & G & 1.23 & $(0.49-3.09)$ & 0.66 \\
& UC & AG & 2.76 & $(0.88-8.61)$ & 0.08 \\
Thr3991le & CD & CT & 2.07 & $(0.72-5.92)$ & 0.17 \\
& & T & 3.35 & $(0.84-13.35)$ & 0.09 \\
& \multirow{4}{*}{ UC } & CT & 3.24 & $(0.83-12.74)$ & 0.09 \\
& & TT & 1.14 & $(0.11-11.29)$ & 0.91 \\
& & T & 10.11 & $(0.40-254.1)$ & 0.16 \\
& & & 3.4 & $(0.67-17.25)$ & 0.14 \\
\hline
\end{tabular}

pathogenesis, genetic influence of pattern recognition receptors was clearly suggested as a trigger of CD and UC. Several efforts were undertaken to demonstrate associations of the human TLR4 gene (Gene map locus 9q32q33) with IBD and its clinical manifestation. Attention was focused on co-segregating SNPs located in exon 3 of TLR4 causing amino acid exchanges at positions 299 (Asp299Gly) and 399 (Thr399Ile) which are located in the extracellular domain of the receptor $[17,48]$. Association of TLR4 Asp299Gly with CD was first reported by Braat et al. [30] subsequent studies have had divergent results and showed strong evidence of ethnic differences. In view of the discrepant data regarding the association of the TLR4 gene with IBD and its clinical complications, we investigated for the first time the potential influence of TLR4 SNPs in the susceptibility to IBD in a cohort of Moroccan patients. However, the statistical power was very low and could be considered a limitation in this study. Our study showed that the GG genotype was not found in both $\mathrm{CD}$ and UC patients. No significant differences were observed in allele frequencies of the TLR4Asp299Gly among patients and controls. In addition, although slightly increased frequencies of the mutant alleles were encountered, we were not able to identify a significant difference in allele distributions of the TLR4Thr399Ile in our case control study. In line with our results, a Tunisian study that genotyped 90 patients with $\mathrm{CD}$ and 80 healthy individuals for the Asp299Gly and Thr399Ile polymorphisms, reported the absence of association between CD and TLR4 gene in a north African population [40]. Although the Tunisian CD population showed a similar overall pattern of allelic frequencies, it is of some note that the genotype-phenotype correlation revealed divergent results. While the Thr399Ile variant allele was associated with early disease onset in Tunisian patients, no correlation with a particular phenotype was observed for this polymorphism in the Moroccan patients. Our study showed that the presence of Asp299Gly variant allele was associated with the need for surgery in UC patients $(P=0.004)$. Furthermore, the occurrence of one Asp299gly risk allele in CD patients was suggestive

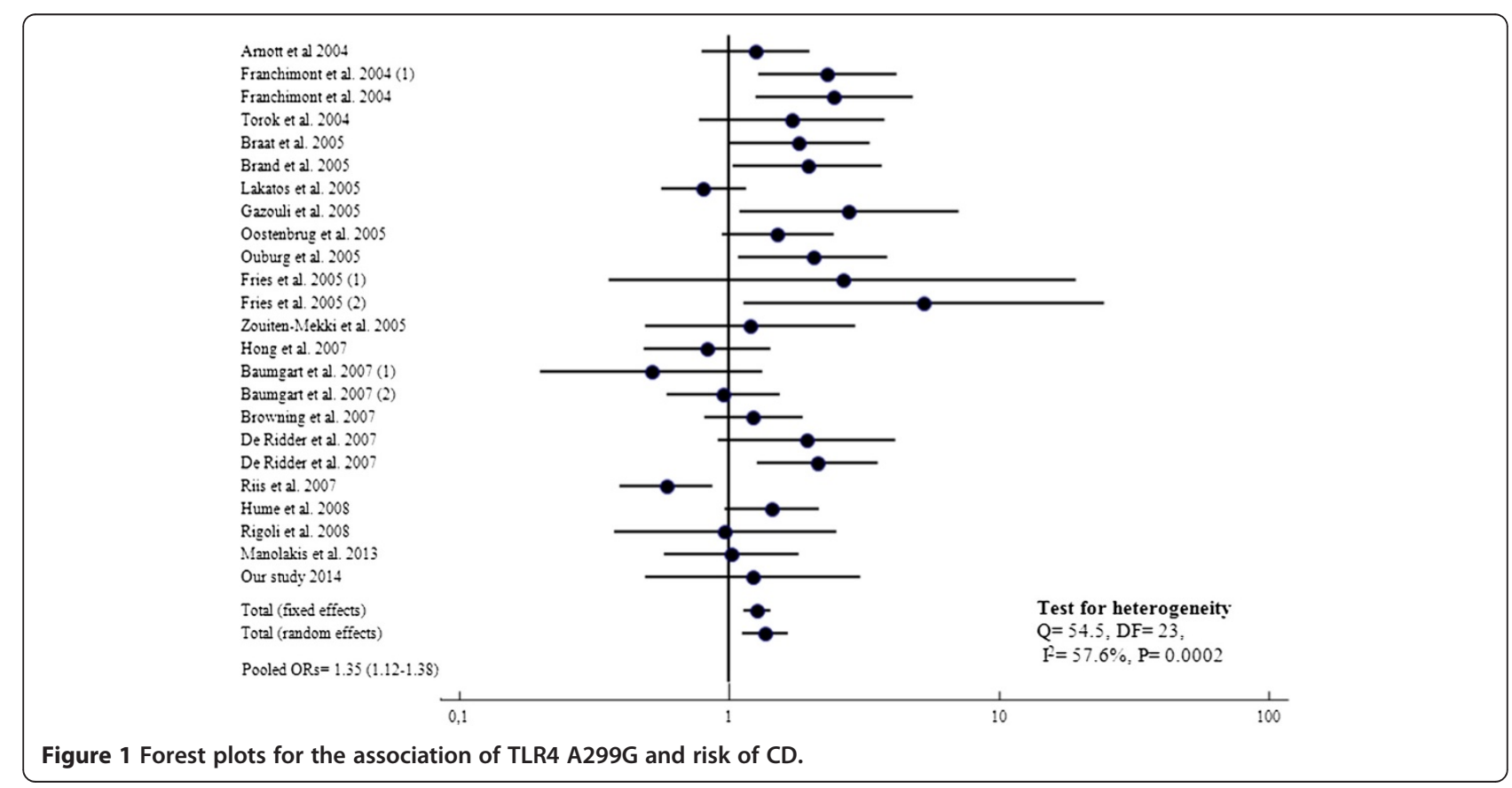




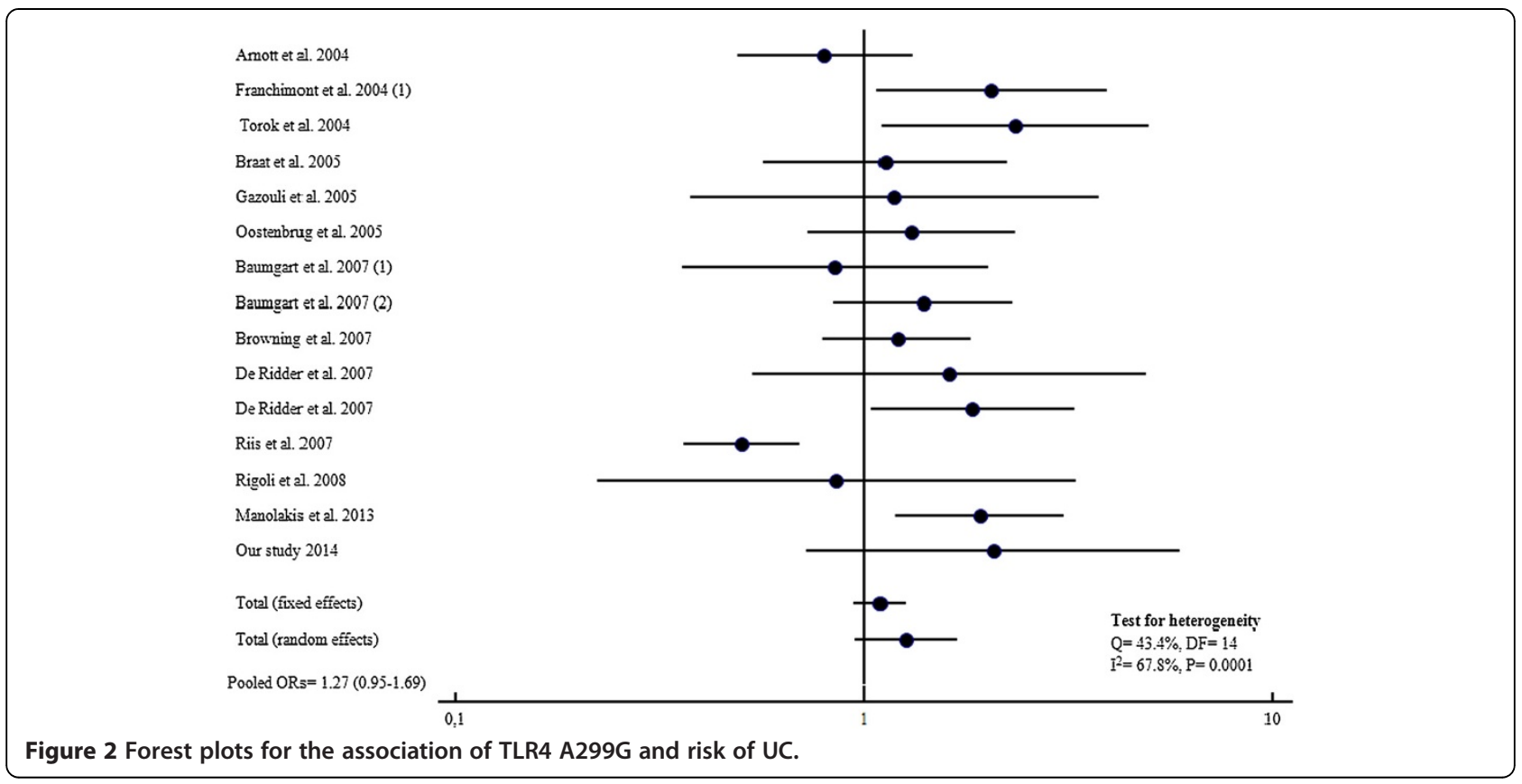

of a trend of association with smoking habits $(\mathrm{P}=0.04)$ that was no more observed after correction for multiple testing.

Being in linkage disequilibrium, TLR4 mutant alleles are known to be inherited in the form of Asp299Gly/Thr399Ile haplotype [48]. In a German cohort, the co-segregation between mutant alleles represented 100\% in controls, whereas it was not complete in CD and UC patients: $94 \%$ and $86 \%$ respectively [33]. These observations contrast our findings where simultaneous presence of the mutated alleles was only observed in $33 \%$ of controls, $33 \%$ of UC and $60 \%$ of CD patients.

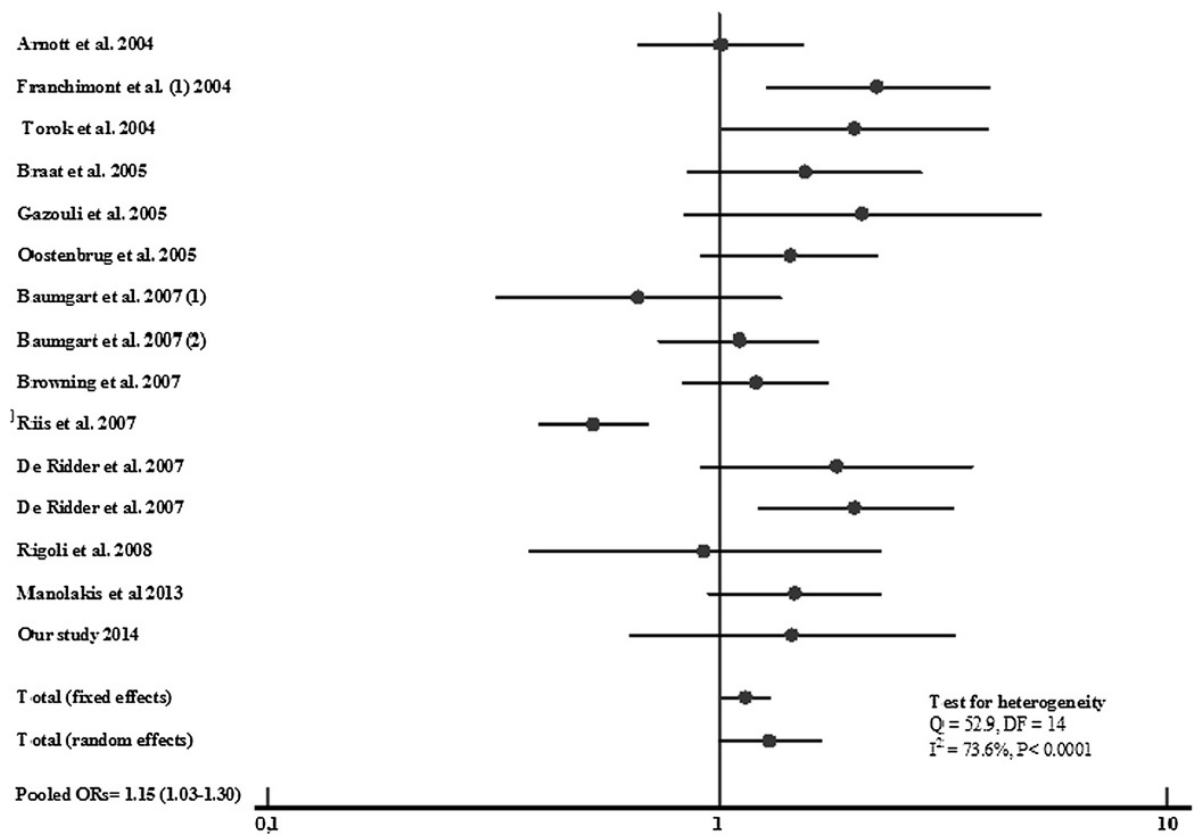

Figure 3 Forest plots for the association of TLR4 A299G and risk of IBD. 


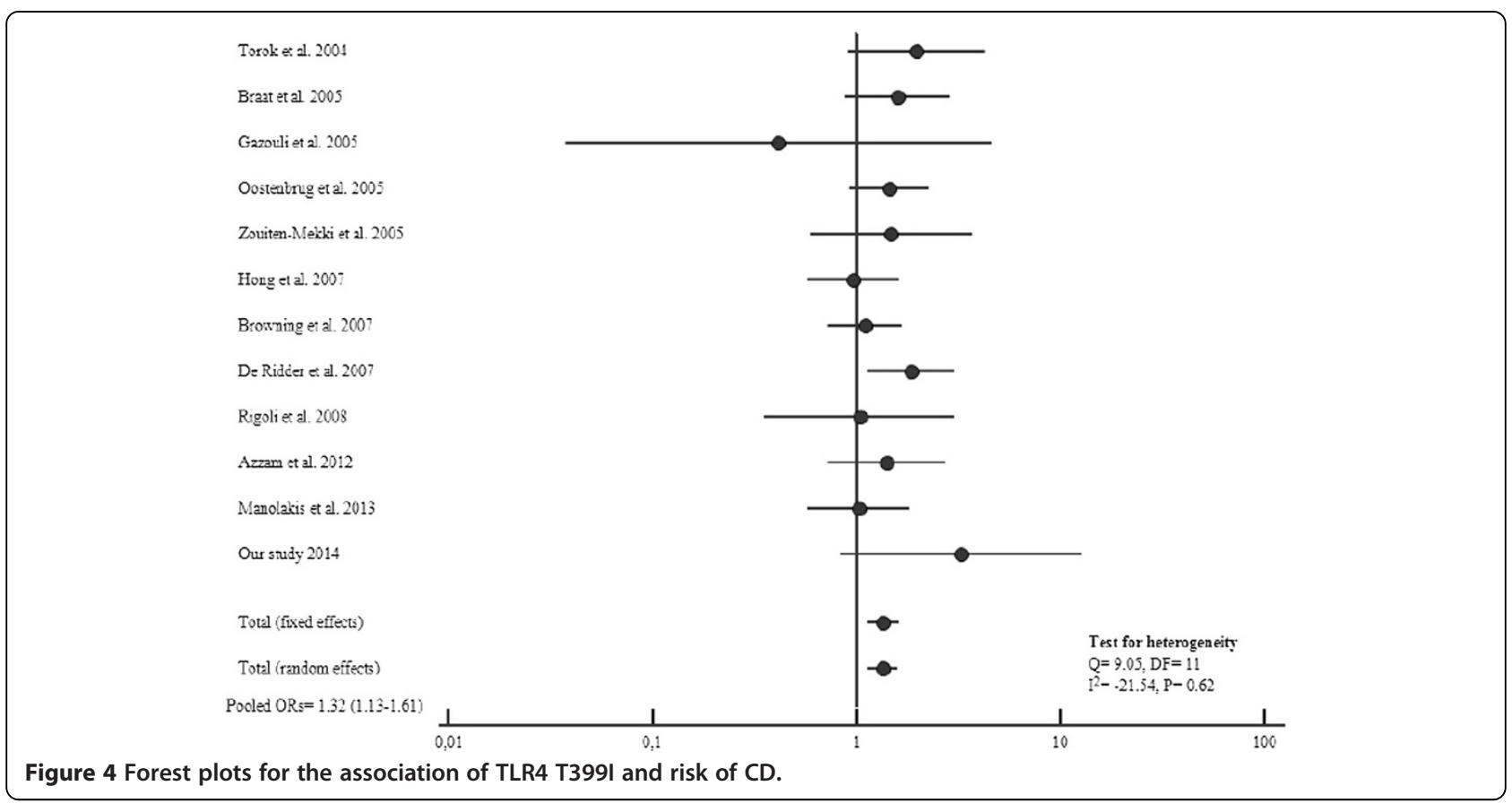

Results on the relationship of Asp299Gly SNP alone or in combination with Thr399Ile with IBD are inconsistent between studies. No difference in TLR4 allele frequency between IBD patients and controls was observed in Hungarian [35], Saudi Arabian [47], Southern Italian
[45], New Zealandian [41] and EC-IBD [43] study groups populations. Genetic heterogeneity within Europe was evidenced by Arnott et al. when reporting lack of association of TLR4 and CD14 variants in Scottish and Irish CD patients [31]. Moreover, Baumgart DC et al. reported

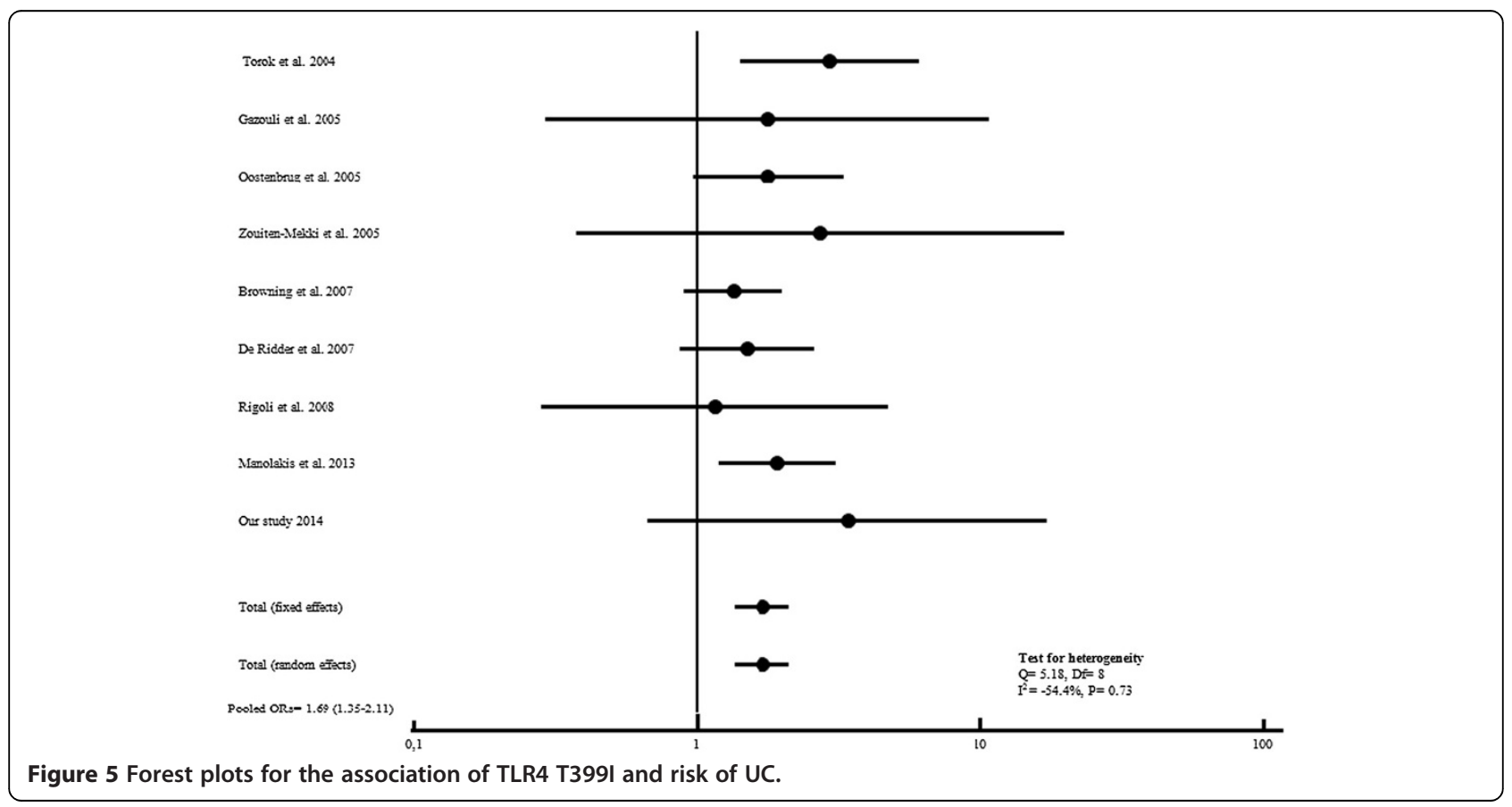




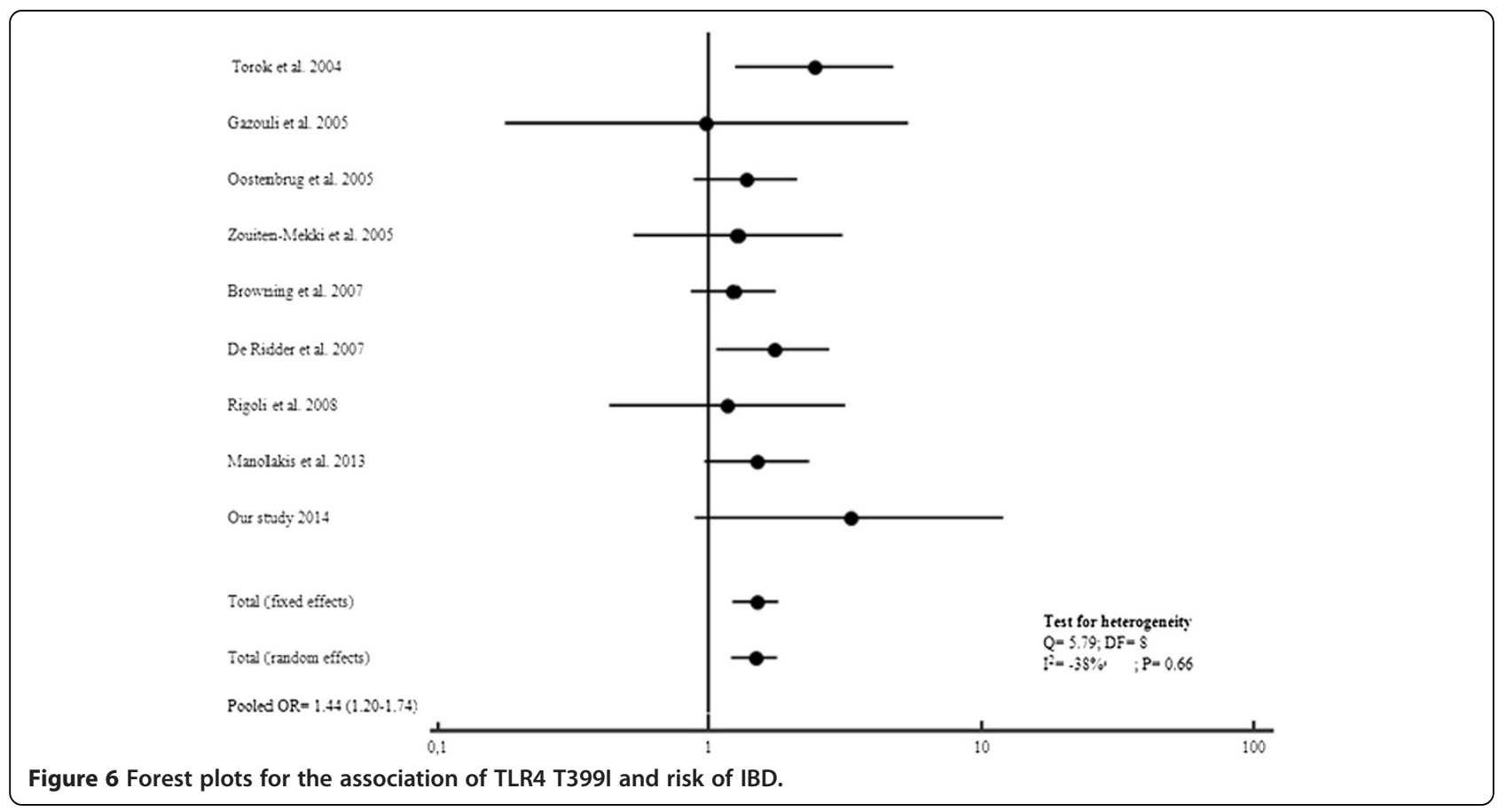

an association between IBD and the CD14 c.1-260C T promoter but not with the TLR4 (p.D299G) variant in Germans and Hungarians [21]. Interestingly, the heterozygous and homozygous pattern for the mutated allele was not detected in any of the individuals from the Japanese [49], Korean [24], Chinese Han population [25] and Zhuang population from the Guangxi Zhuang Autonomous Region of China [26]. TLR4 was linked to an increased IBD (CD or UC) risk in many other diverse investigations. Significant associations were found in patients drawn from Belgian [32], German [22,33], Greek $[36,46]$ and Dutch [34] populations. In addition, several meta-analyses provided evidence that the Asp299Gly SNP is associated with CD and IBD in Caucasians $[27,42,50]$. The results of our meta-analysis indicate a significant association between TLR4 Thr399Ile and $\mathrm{CD}$ and UC risk in different populations. Noteworthy, a lack of heterogeneity between studies was observed regarding distribution of this polymorphism. The results support that this variant is a potential risk factor for IBD.

A correlation between Asp299Gly variant and an increased disease risk is also reported for CD and IBD but not regarding UC, which is in line with de Jager et al. findings [28]. This indicates that the risk allele is either not associated with disease susceptibility or that the small number of UC cohorts did not provide sufficient power to detect an association. A correlation between TLR4 polymorphisms and UC has been rarely discussed, more association studies are needed to validate the conclusion.

To date it is well known that the frequency of the investigated TLR4 gene SNPs varies between populations $[27,31]$. Overall, there was inescapable evidence for considerable genetic heterogeneity. This observation has been explained by geographic and ethnicity-related gene effect on disease susceptibility [51]. Our results showed that the distribution of the risk alleles varies between both TLR4 polymorphisms. Therefore, we offer additional evidence for differences in the contribution of individual genetic determinants between populations. Browning et al., argued that negative studies with results that do not achieve statistical significance can still contribute evidence for association, having important implications for the first generation of whole genome association studies [42].

In view of the role of potential confounders related to the present study and to discrepant results between populations, it is likely that the contribution of different sample size, selection bias, phenotypic heterogeneity and population stratification in case control studies can $t$ be ruled out. These data demonstrate further the real difficulties in candidate gene analysis in complex diseases. Moreover, given that IBD is a polygenic disease it is provided that association studies will reveal various sets of susceptible genes. Therefore, further large-scale studies are required to obtain a clear insight into the impact of the pattern recognition receptors in the 
Table 9 Genotype-phenotype correlations in patients with Crohn s disease

\begin{tabular}{|c|c|c|c|c|c|c|c|c|c|c|c|}
\hline \multirow[t]{2}{*}{ Parameter } & \multirow[t]{2}{*}{$\mathbf{N}$} & \multicolumn{3}{|c|}{ Asp299gly (\%) } & \multirow[t]{2}{*}{$P$ value } & \multirow[t]{2}{*}{ Chi-square test } & \multicolumn{3}{|c|}{ Thr399lle (\%) } & \multirow[t]{2}{*}{$P$ value } & \multirow[t]{2}{*}{ Chi-square test } \\
\hline & & $A A$ & AG & GG & & & $\mathrm{CC}$ & CT & $\pi$ & & \\
\hline Age of onset & 83 & & & & 0.48 & 1.45 & & & & 0.59 & 1.05 \\
\hline$<17$ years & 10 & $10(100.0)$ & - & & & & $10(100.0)$ & - & & & \\
\hline $17-40$ & 63 & 55 (87.3.) & $8(12.7)$ & & & & $57(90.5)$ & $6(9.5)$ & & & \\
\hline$>40$ years & 10 & $9(90.0)$ & $1(10.0)$ & & & & $9(90.0)$ & $1(10.0)$ & & & \\
\hline Sex & 83 & & & & 0.35 & 0.87 & & & & 0.17 & 1.92 \\
\hline Woman & 25 & $24(96.0)$ & $1(4.0)$ & & & & $25(100.0)$ & - & & & \\
\hline Man & 58 & $50(86.2)$ & $8(13.8)$ & & & & $51(87.9)$ & $7(12.1)$ & & & \\
\hline Type & 83 & & & & 0.54 & 2.14 & & & & 0.36 & 3.23 \\
\hline Fistulizing & 35 & $31(88.6)$ & $4(11.4)$ & & & & $33(94.3)$ & $2(5.7)$ & & & \\
\hline Non fistulizing non stenosing & 24 & $20(83.3)$ & $4(16.7)$ & & & & $20(83.3)$ & $(16.7)$ & & & \\
\hline Stenosing & 17 & $16(94.1)$ & $1(5.9)$ & & & & $16(94.1)$ & $1(5.9)$ & & & \\
\hline Fistulizing stenosing & 7 & $7(100.0)$ & - & & & & $7(100.0)$ & - & & & \\
\hline Localization & 83 & & & & 0.80 & 1.67 & & & & 0.94 & 0.82 \\
\hline L1 & 30 & $26(86.7)$ & $4(13.3)$ & & & & $27(90.0)$ & $3(10.0)$ & & & \\
\hline L2 & 20 & $17(85.0)$ & $3(5.0)$ & & & & $18(90.0)$ & $2(10.0)$ & & & \\
\hline L3 & 26 & $24(92.3)$ & 20 & & & & $24(92.3)$ & $2(7.7)$ & & & \\
\hline$\llcorner 4$ & 3 & $3(100.0)$ & - & & & & $3(100.0)$ & - & & & \\
\hline$L 4+L 2$ & 4 & $4(100.0)$ & - & & & & $4(100.0)$ & - & & & \\
\hline Smoking & 83 & & & & 0.04 & 4.44 & & & & 0.17 & 1.92 \\
\hline Presence & 33 & $26(78.8)$ & $7(21.2)$ & & & & $28(84.8)$ & $5(15.2)$ & & & \\
\hline Absence & 50 & $48(96.0)$ & $2(4.0)$ & & & & $48(96)$ & $2(4.0)$ & & & \\
\hline SFC & 83 & & & & 0.91 & 0.01 & & & & 0.76 & 0.09 \\
\hline Presence & 4 & $4(100.0)$ & - & & & & $4(100.0)$ & - & & & \\
\hline Absence & 79 & 70 (88.6) & $9(11.4)$ & & & & $72(91.1)$ & $7(8.9)$ & & & \\
\hline Appendectomy & 83 & & & & 0.84 & 0.04 & & & & 0.58 & 0.30 \\
\hline Presence & 12 & $11(91.7)$ & $1(8.3)$ & & & & 10 (83.3) & $2(16.7)$ & & & \\
\hline Absence & 71 & $63(88.7)$ & $8(11.3)$ & & & & $66(93.0)$ & $5(7.0)$ & & & \\
\hline EIM & 83 & & & & 0.97 & 0.001 & & & & 0.97 & 0.001 \\
\hline Presence & 42 & $38(90.5)$ & $4(9.5)$ & & & & 39 (92.9) & $3(7.1)$ & & & \\
\hline Absence & 41 & 36 (87.8) & $5(12.2)$ & & & & 37 (95.1) & $4(4.9)$ & & & \\
\hline Surgery & 83 & & & & 0.50 & 0.45 & & & & 0.45 & 0.57 \\
\hline Presence & 41 & $38(92.7)$ & $3(7.3)$ & & & & $39(95.1)$ & $2(4.9)$ & & & \\
\hline Absence & 42 & $36(85.7)$ & $6(14.3)$ & & & & 37 (88.1) & $5(11.9)$ & & & \\
\hline
\end{tabular}

SFC: similar familial cases; EIM: extra intestinal manifestations; N: total number; AA: wild type TLR4 Asp299gly, AG: TLR4 Asp299gly heterozygous variant, GG: TLR4 Asp299gly homozygous variant; CC: wild type TLR4 Thr399lle, CT: TLR4 Thr399lle heterozygous variant, TT: TLR4 Thr399lle homozygous variant.

pathophysiological and immunogenetic aspects of IBD and to explore the contribution of other genes involved in various processes.

\section{Conclusions}

In the present study, we have demonstrated that the common mutations in the TLR4 gene are not associated with IBD in a sample of Moroccan patients. However, our dataset contributed to the significant association observed in TLR4 meta-analysis.

It is likely that the distribution of TLR4 gene polymorphisms have ethnic differences. Our data suggests that other genetic and environmental factors may play a role in IBD susceptibility and behavior in this population. However, because of the relatively small sample size, additional well-powered studies are needed to confirm our findings. 
Table 10 Genotype-phenotype correlations in patients with ulcerative colitis

\begin{tabular}{|c|c|c|c|c|c|c|c|c|c|c|c|}
\hline \multirow[t]{2}{*}{ Parameter } & \multirow[t]{2}{*}{$\mathbf{N}$} & \multicolumn{3}{|c|}{ Asp299gly (\%) } & \multirow{2}{*}{$\begin{array}{l}P \\
\text { value }\end{array}$} & \multirow[t]{2}{*}{ Chi-square test } & \multicolumn{3}{|c|}{ Thr399lle (\%) } & \multirow[t]{2}{*}{$P$ value } & \multirow[t]{2}{*}{ Chi-square test } \\
\hline & & AA & AG & GG & & & $\mathrm{CC}$ & $\mathrm{CT}$ & TT & & \\
\hline Age of onset & 34 & & & & 0.35 & 0.89 & & & & 0.34 & 2.13 \\
\hline$<17$ years & - & - & - & & & & - & - & & & \\
\hline $17-40$ & 20 & $18(90.0)$ & $2(10.0)$ & - & & & $19(95.0)$ & $1(5.0)$ & - & & \\
\hline$>40$ years & 14 & $10(71.4)$ & $4(28.6)$ & - & & & $13(92.9)$ & - & $1(7.1)$ & & \\
\hline Sex & 34 & & & & 0.89 & 0.018 & & & & 0.36 & 2.06 \\
\hline Woman & 15 & $13(86.7)$ & $2(13.3)$ & - & & & $14(93.3)$ & $1(6.7)$ & - & & \\
\hline Man & 19 & $15(78.9)$ & $4(21.1)$ & - & & & $18(94.7)$ & - & $1(5.3)$ & & \\
\hline Extent of the disease & 34 & & & & 0.31 & 3.55 & & & & 0.16 & 9.34 \\
\hline E1 & 4 & $2(50.0)$ & $2(50.0)$ & - & & & $3(75.0)$ & - & $1(25.0)$ & & \\
\hline E2 & 15 & $13(86.7)$ & $2(13.3)$ & - & & & $15(100.0)$ & - & - & & \\
\hline E3 & 2 & $2(100.0)$ & - & - & & & $2(100.0)$ & - & - & & \\
\hline E4 & 13 & $11(84.6)$ & $2(15.4)$ & - & & & $12(92.3)$ & $1(7.7)$ & - & & \\
\hline SFC & 34 & & & & 0.39 & 0.74 & & & & 0.97 & 0.06 \\
\hline Presence & 1 & $1(100.0)$ & - & - & & & $1(100.0)$ & - & & & \\
\hline Absence & 33 & 27 (81.8) & $6(18.2)$ & - & & & 31 (93.9) & $1(3.0)$ & $1(3.0)$ & & \\
\hline Smoking & 34 & & & & 0.93 & 0.008 & & & & 0.20 & 3.17 \\
\hline Presence & 9 & 7 (77.8) & $2(22.2)$ & - & & & $8(88.9)$ & - & $1(11.1)$ & & \\
\hline Absence & 25 & 21 (84.) & $4(16.0)$ & - & & & $24(96.0)$ & $1(4.0)$ & - & & \\
\hline EIM & 34 & & & & 0.89 & 0.018 & & & & 0.35 & 2.05 \\
\hline Presence & 19 & 15 (78.9) & $4(21.1)$ & - & & & 18 (94.7) & - & $1(5.3)$ & & \\
\hline Absence & 15 & 13 (86.7) & $2(13.3)$ & - & & & 14 (93.3) & $1(6.7)$ & - & & \\
\hline Surgery & 34 & & & & 0.004 & 8.3 & & & & 0.08 & 4.97 \\
\hline Presence & 6 & $2(33.3)$ & $4(66.7)$ & - & & & $5(83.3)$ & $1(16.7)$ & - & & \\
\hline Absence & 28 & 26 (92.9) & $2(7.1)$ & - & & & 27 (96.4) & - & $1(3.6)$ & & \\
\hline
\end{tabular}

SFC: similar familial cases; EIM: extra intestinal manifestations; N: total number; AA: wild type TLR4 Asp299gly, AG: TLR4 Asp299gly heterozygous variant, GG: TLR4 Asp299gly homozygous variant; CC: wild type TLR4 Thr399lle, CT: TLR4 Thr399lle heterozygous variant, T: TLR4 Thr399lle homozygous variant.

\section{Abbreviations}

IBD: Inflammatory bowel disease; CD: Crohn s disease; UC: Ulcerative colitis; PRR: Pattern recognition receptors.

\section{Competing interests}

The authors declare that they have no competing interests.

\section{Authors contributions}

NS out the molecular genetic studies, participated in the recruitment of patients and drafted the manuscript. BD performed the statistical analysis. NS participated in recruitment of patients and clinical data collection. $Y Z$ revised the manuscript. WB coordinated patient s recruitment and provided the clinical data. SN conceived the study and participated in its design and coordination. All authors read and approved the final manuscript.

\section{Acknowledgements}

We gratefully acknowledge the members of LGMP and the Gastroenterology department. We are also indebted to Mr. Wifaq Said, Center of Doctoral studies, for his help and for the secretarial assistance.

\section{Author details}

${ }^{1}$ Laboratory of Genetic and Molecular Pathology (LGPM), Medical School, Hassan II University, Casablanca, Morocco. ${ }^{2}$ Gastroenterology Department, CHU Ibn Rochd, Casablanca, Morocco. ${ }^{3}$ Laboratory of Thrombosis and Haemostasis Research Centre, Montreal Heart Institute, 5000 Belanger Street, Montreal, QC H1T 1C8, Canada.
Received: 22 June 2014 Accepted: 24 November 2014

Published online: 10 December 2014

\section{References}

1. Shanahan F, Bernstein CN: The evolving epidemiology of inflammatory bowel disease. Curr Opin Gastroenterol 2009, 25(4):301 305

2. Sobczak M, Fabisiak A, Murawska N, Wesołowska E, Wierzbicka P, Wlazłowski M, Wjcikowska M, Zatorski H, Zwoli ńska M, Fichna J: Current overview of extrinsic and intrinsic factors in etiology and progression of inflammatory bowel diseases. Pharmacol Rep 2014, 66(5):766 775.

3. Rock FL, Hardiman G, Timans JC, Kastelein RA, Bazan JF: A family of human receptors structurally related to Drosophila Toll. Proc Natl Acad Sci U S A 1998, 95:588 593.

4. Takeda K, Kaisho T, Akira S: Toll-like receptors. Annu Rev Immuno/ 2003, 21:335 376 .

5. Kumar H, Kawai T, Akira S: Toll-like receptors and innate immunity. Biochem Biophys Res Commun 2009, 388:621 625.

6. Medzhitov R, Preston-Hurlburt P, Janeway CA Jr: A human homologue of the Drosophila Toll protein signals activation of adaptive immunity. Nature 1997, 388(6640):394 397.

7. Akira S, Takeda K, Kaisho T: Toll-like receptors: critical proteins linking innate and acquired immunity. Nat Immunol 2001, 2:675 680.

8. Chow JC, Young DW, Golenbock DT, Christ WJ, Gusovsky F: Toll-like receptor-4 mediates lipopolysaccharide-induced signal transduction. J Biol Chem 1999, 274:10689 10692. 
9. Fitzgerald KA, Palsson McDermott EM, Bowie AG, Jefferies CA, Mansell AS, Brady G, Brint E, Dunne A, Gray P, Harte MT, McMurray D, Smith DE, Sims JE, Bird TA, O'Neill LA: Mal (MyD88-adapter-like) is required for Tolllike receptor-4 signal transduction. Nature 2001, 413(6851):78 83.

10. Otte JM, Cario E, Podolsky DK: Mechanisms of cross hyporesponsiveness to Toll-like receptor bacterial ligands in intestinal epithelial cells. Gastroenterology 2004, 126:1054 1070.

11. Abreu MT, Vora P, Faure E, Thomas LS, Arnold ET, Arditi M: Decreased expression of Toll-like receptor- 4 and MD-2 correlates with intestinal epithelial cell protection against dysregulated proinflammatory gene expression in response to bacterial lipopolysaccharide. J Immunol 2001, 167:1609 1616.

12. Cario E, Podosky DK: Differential alteration in intestinal epithelial cell expression of Toll-like receptor 3 (TLR3) and TLR4 in inflammatory bowel disease. Infect Immun 2000, 68:7010 7017 .

13. Hausmann M, Kiessling S, Mestermann S, Webb G, Spttl T, Andus T, Schlmerich J, Herfarth H, Ray K, Falk W, Rogler G: Toll-like receptors 2 and 4 are up-regulated during intestinal inflammation. Gastroenterology 2002, 122:1987 2000.

14. Singh JC, Cruickshank SM, Newton DJ, Wakenshaw L, Graham A, Lan J, Lodge JP, Felsburg PJ, Carding SR: Toll-like receptor mediated responses of primary intestinal epithelial cells during the development of colitis. Am J Physio/Gastrointest Liver Physiol 2005, 288:G514 G524.

15. Frolova L, Drastich P, Rossmann P, Klimesova K, Tlaskalova-Hogenova H: Expression of Toll-like receptor 2 (TLR2), TLR4, and CD14 in biopsy samples of patients with inflammatory bowel diseases: upregulated expression of TLR2 in terminal ileum of patients with ulcerative colitis. J Histochem Cytochem 2008, 56:267 274

16. Szebeni B, Veres G, Dezsfi A, Rusai K, Vannay A, Mraz M, Majorova E, Arat A: Increased expression of Toll-like receptor (TLR) 2 and TLR4 in the colonic mucosa of children with inflammatory bowel disease. Clin Exp Immunol 2008, 151:34 41.

17. Arbour NC, Lorenz E, Schutte BC: TLR4 mutations are associated with endotoxin hyporesponsiveness in humans. Nat Genet 2000, 25:187 191.

18. Senhaji N, Serbati N, Diakit B, Arazzakou S, Hamzi K, Badre W, Nadifi S: Methylenetetrahydrofolatereductase C677T variant in Moroccan patients with inflammatory bowel disease. Gene 2013, 521(1):45 49.

19. Serbati N, Senhaji N, Diakite B, Badre W, Nadifi S: IL23R and ATG16L1 variants in Moroccan patients with inflammatory bowel disease. BMC Res Notes 2014, 7(1):570.

20. Silverberg MS, Satsangi J, Ahmad T, Arnott ID, Bernstein CN, Brant SR, Caprilli R, Colombel JF, Gasche C, Geboes K, Jewell DP, Karban A, Loftus EV Jr, Pea AS, Riddell RH, Sachar DB, Schreiber S, Steinhart AH, Targan SR, Vermeire S, Warren BF: Toward an integrated clinical, molecular and serological classification of inflammatory bowel disease: report of a working party of the 2005 Montreal World Congress of Gastroenterology. Can J Gastroenterol 2005, 19:5 36.

21. Baumgart DC, Buning C, Geerdts L, Schmidt HH, Genschel J, Fiedler T, Gentz E, Molnar T, Nagy F, Lonovics J, Lochs H, Wiedenmann B, Nickel R, Witt H Dignass A: The c.1 260C > T promoter variant of CD14 but not the $c .896 \mathrm{~A}>$ $\mathrm{G}$ (p.D299G) variant of toll-like receptor 4 (TLR4) genes is associated with inflammatory bowel disease. Digestion 2007, 76:196 202.

22. Brand S, Staudinger T, Schnitzler F, Pfennig S, Hofbauer K, Dambacher J, Seiderer J, Tillack C, Konrad A, Crispin A, Goke B, Lohse P, Ochsenkuhn T: The role of Toll-like receptor 4 Asp299Gly and Thr399lle polymorphisms and CARD15/NOD2 mutations in the susceptibility and phenotype of Crohn s disease. Inflamm Bowel Dis 2005, 11:645 652.

23. de Ridder L, Weersma RK, Dijkstra G, van der Steege G, Benninga MA, Nolte IM, Taminiau JA, Hommes DW, Stokkers PC: Genetic susceptibility has a more important role in pediatric-onset Crohn s disease than in adult-onset Crohns disease. Inflamm Bowel Dis 2007, 13:1083 1092.

24. Kim EJ, Chung WC, Lee KM, Paik CN, Jung SH, Lee Bl, Chae HS, Choi KY: Association between toll-like receptors/CD14 gene polymorphisms and inflammatory bowel disease in Korean population. J Korean Med Sci 2012, 27:72 77

25. Guo QS, Xia B, Jiang Y, Morre SA, Cheng L, Li J, Crusius JB, Pena AS: Polymorphisms of CD14 gene and TLR4 gene are not associated with ulcerative colitis in Chinese patients. Postgrad Med J 2005, 81:526 529.

26. Chen L, Lin MJ, Zhan LL, LV XP: Analysis of TLR4 and TLR2 polymorphisms in inflammatory bowel disease in a Guangxi Zhuang population. World J Gastroenterol 2012, 18:6856 6860 .
27. Shen $X$, Shi R, Zhang H, Li K, Zhao Y, Zhang R: The Toll-like receptor 4 D299G and T399l polymorphisms are associated with Crohns disease and ulcerative colitis: a meta-analysis. Digestion 2010, 81(2):69 77.

28. De Jager PL, Franchimont D, Waliszewska A, Bitton A, Cohen A, Langelier D, Belaiche J, Vermeire S, Farwell L, Goris A, Libioulle C, Jani N, Dassopoulos T, Bromfield GP, Dubois B, Cho JH, Brant SR, Duerr RH, Yang H, Rotter II, Silverberg MS, Steinhart AH, Daly MJ, Podolsky DK, Louis E, Hafler DA, Rioux JD: The role of the Toll receptor pathway in susceptibility to inflammatory bowel diseases. Genes Immun 2007, 8:387 397.

29. Figueroa C, Peralta A, Herrera L, Castro P, Gutierrez A, Valenzuela J, Aguillon JC, Quera A, Hermoso MA: NOD2/CARD15 and Toll-like 4 receptor gene polymorphism in Chilean patientes with inflammatory bowel disease. Eur Cytokine Netw 2006, 17:125.1340.

30. Braat H, Dijgraaf M, Curvers W, Vogels E, Bodegraven AV, Stokkers $P$, Hommes D, Deventer SV: A functional single polymorphism of the TLR4 gene is correlated Crohns disease but not with ulcerative colitis. Gastroenterology 2003, 124:A367.

31. Arnott IDR, Nimmo ER, Drummond HE, Fennell J, Smith BR, MacKinlay E, Morecroft J, Anderson N, Kelleher D, O'Sullivan M, McManus R, Satsangi J: NOD2/CARD15, TLR4 and CD14 mutations in Scottish and Irish Crohns disease patients: evidence for genetic heterogeneity within Europe? Genes Immun 2004, 5:417 425.

32. Franchimont $D$, Vermeir $S$, El Housni H, Pierik M, Van Steen $K$, Gustot $T$, Quertinmont E, Abramowicz M, Van Gossum A, Devire J, Rutgeerts P. Deficient host-bacteria interactions in inflammatory bowel disease? The toll-like receptor (TLR)-4 Asp 299Gly polymorphism is associated with Crohn s disease and ulcerative colitis. Gut 2004, 53:987 992

33. Torok HP, Glas J, Tonenchi L, Mussack T, Folwaczny C: Polymorphisms of the lipopolysaccharide-signaling complex in inflammatory bowel disease: association of a mutation in the toll-like receptor 4 gene with ulcerative colitis. Clin Immunol 2004, 112:85 91.

34. Braat $H$, Stokkers $P$, Hommes T, Cohn D, Vogels E, Pronk I, Spek A, van Kampen A van Deventer S, Peppelenbosch M, Hommes D: Consequence of functional Nod2 and Tlr4 mutations on gene transcription in Crohns disease patients. J Mol Med (Berl) 2005, 83(8):601 609.

35. Lakatos PL, Lakatos L, Szalay F, Willheim-Polli C, sterreicher C, Tulassay Z, Molnar T, Reinisch W, Papp J, Mozsik G, Ferenci P, Hungarian IBD Study Group: Toll-like receptor 4 and NOD2/CARD15 mutations in Hungarian patients with Crohn s disease: Phenotype-genotype correlations. World J Gastroenterol 2005, 11:1489 1495.

36. Gazouli M, Mantzaris G, Kotsinas A, Zacharatos P, Papalambros E, Archimandritis E, Ikonomopoulos J, Gorgoulis VG: Association between polymorphisms in the Toll-like receptor 4, CD14 and CARD15/NOD2 and inflammatory bowel disease in the Greek population. W J Gastroenterol 2005, 11:681 685 .

37. Oostenbrug LE, Drenth JP, de Jong DJ, Nolte IM, Oosterom E, van Dullemen HM, van der Linde K, te Meerman GJ, van der Steege G, Kleibeuker JH, Jansen PL: Association between Toll-like receptor 4 and inflammatory bowel disease. Inflamm Bowel Dis 2005, 11(6):567 575.

38. Ouburg S, Mallant-Hent R, Crusius JBA, van Bodegraven AA, Mulder CJJ, Linskens R, Pena AS, Morre SA: The toll-like receptor 4 (TLR4) Asp299Gly polymorphism is associated with colonic localisation of Crohn s disease without a major role for the Saccharomyces cerevisiae mannan-LBPCD14-TLR4 pathway. Gut 2005, 54(3):439 440.

39. Fries W, Renda MC, Lo Presti MA, Raso A, Orlando A, Oliva L, Giofr MR, Maggio A, Mattaliano A, Macaluso A, Cottone M: Intestinal permeability and genetic determinants in patients, first-degree relatives, and controls in a high-incidence area of Crohns disease in southern Italy. Am J Gastroenterol 2005, 100:2730 2736

40. Zouiten-Mekki L, Kharrat M, Karoui S, Serghimi M, Fekih M, Matri S, Kallel L, Boubaker J, Filali A, Chaabouni H: Tolllike receptor 4 (TLR4) polymorphisms in Tunisian patients with Crohn s disease: genotypephenotype correlation. BMC Gastroenterol 2009, 9:62.

41. Hong J, Leung E, Fraser AG, Merriman TR, Vishnu P, Krissansen GW: TLR2, TLR4 and TLR9 polymorphisms and Crohn s disease in a New Zealand Caucasian cohort. J Gastroenterol Hepatol 2007, 22(11):1760 1766.

42. Browning BL, Huebner C, Petermann I, Gearry RB, Barclay ML, Shelling AN, Ferguson LR: Has toll-like receptor 4 been prematurely dismissed as an inflammatory bowel disease gene? Association study combined with meta-analysis shows strong evidence for association. Am J Gastroenterol 2007, 102:2504 2512. 
43. Riis L, Ida V, Severine V, Frank W, Kostas K, Patrizia P, Joo F, Mouzas IA, O'Morain C, Ruiz-Ochoa V, Odes S, Binder V, Munkholm P, Moum B, Stockbrgger R, Langholz E, European Collaborative Study Group on Inflammatory Bowel Disease: The prevalence of genetic and serologic markers in an unselected European population-based cohort of IBD patients. Inflamm Bowel Dis 2007, 13(1):24 32.

44. Hume GE, Fowler EV, Doecke J, Simms LA, Huang N, Palmieri O, Griffiths LR, Florin TH, Annese V, Radford-Smith GL: Novel NOD2 haplotype strengthens the association between TLR4 Asp299Gly and Crohns disease in an Australian population. Inflamm Bowel Dis 2008, 14:585 590.

45. Rigoli L, Romano C, Caruso RA, Lo Presti MA, Di Bella C, Procopio V, Lo Giudice G, Amorini M, Costantino G, Sergi MD, Cuppari C, Calabro GE, Gallizzi R, Salpietro CD, Fries W: Clinical significance of NOD2/CARD15 and Toll-like receptor 4 gene single nucleotide polymorphisms in inflammatory bowel disease. World J Gastroenterol 2008, 14:4454 4461.

46. Manolakis CA, Kapsoritakis NA, Kapsoritaki A, Tiaka EK, Oikonomou AK, Lotis V, Vamvakopoulou D, Davidi I, Vamvakopoulos N, Potamianos SP: Readressing the role of toll-like receptor-4 alleles in inflammatory bowel disease: colitis, smoking, and seroreactivity. Dig Dis Sci 2013, 58(2):371 380

47. Azzam N, Nounou H, Alharbi O, Aljebreen A, Shalaby M: CARD15/NOD2, CD14 and toll-like 4 receptor gene polymorphisms in Saudi patients with Crohn s disease. Int J Mol Sci 2012, 13:4268 4280.

48. Ferwerda B, McCall MB, Verheijen K, Kullberg BJ, van der Ven AJ, Van der Meer JW, Netea MG: Functional consequences of toll-like receptor 4 polymorphisms. Mol Med 2008, 14:346 352.

49. Okayama N, Fujimura K, Suehiro Y, Hamanaka Y, Fujiwara M, Matsubara T, Maekawa T, Hazama S, Oka M, Nohara H, Kayano K, Okita K, Hinoda Y: Simple genotype analysis of the Asp299Gly polymorphism of the toll-like receptor- 4 gene that is associated with lipopolysaccharide hyporesponsiveness. J Clin Lab Anal 2002, 16:56 58.

50. Shen XY, Shi RH, Wang Y, Zhang HJ, Zhou XQ, Shen FC, Li KB: Toll-like receptor gene polymorphisms and susceptibility to inflammatory bowel disease in Chinese Han and Caucasian populations. Zhonghua Yi XueZaZhi 2010, 90(20):1416 1420.

51. Ali S, Tamboli CP: Advances in epidemiology and diagnosis of inflammatory bowel diseases. Cur Gastroenterol Rep 2008, 10:576 584.

doi:10.1186/s12876-014-0206-x

Cite this article as: Senhaji et al:: Toll-like receptor 4 Asp299Gly and Thr399lle polymorphisms: New data and a meta-analysis. BMC

Gastroenterology 2014 14:206.

\section{Submit your next manuscript to BioMed Central and take full advantage of:}

$\bigotimes$ Convenient online submission

$\otimes$ Thorough peer review

$\nabla$ No space constraints or color $\nabla$ gure charges

$\otimes I m m e d i a t e$ publication on acceptance

Q Inclusion in PubMed, CAS, Scopus and Google Scholar

$\otimes$ Research which is freely available for redistribution 